\title{
The Nutritive Value of Colostrum for the Calf
}

\section{The Effect of Soya-bean Lecithin on the Vitamin A Absorption and on the Growth Rate of Calves Given Small Quantities of Separated Colostrum}

\author{
BY R. ASCHAFFENBURG, S. BARTLETT, S. K. KON, J. H. B. ROY, \\ H. J. SEARS AND S. Y. THOMPSON
}

National Institute for Research in Dairying, University of Reading

AND

P. L. INGRAM, R. LOVELL AND P. C. WOOD

Department of Pathology, Royal Veterinary College, Camden Town, London, N.W. I

(Received 2 Fanuary 1953)

The nutritional importance of lecithin for newborn animals has been demonstrated in America. Esh, Sutton, Hibbs \& Krauss (1948) compared the performance of calves receiving colostrum for the first 7 days of life with that of calves deprived of colostrum but given skim milk containing a daily supplement of 25,000-37,500 i.u. vitamin A, and with that of calves that received in addition $3-4.5 \mathrm{~g}$ of soya-bean lecithin. Three of the five calves given the vitamin A supplement died within the first II days of life, and the remaining two scoured from the $3^{\text {rd }}$ to the Ioth day. Low blood levels indicated that their vitamin A absorption was poor, whereas the blood level and the growth rate of the calves given lecithin as well as vitamin A were similar to those of the colostrum-fed calves. These authors also suggested that the liver storage of vitamin A was appreciably higher in calves given lecithin and vitamin A than in calves given vitamin A alone. Similarly, Esh \& Sutton (1948) found that the addition of lecithin to vitamin $A$ increased weight gains and the liver storage of vitamin $A$ in rats. Sheffy, Gallegos, Grummer, Phillips \& Bohstedt (I95I) found more recently that piglets deprived of colostrum scoured severely and died within 4-5 days unless $5 \%$ of soya-bean lecithin was emulsified with the lard used in their semi-synthetic diet.

In one of our early experiments (Aschaffenburg, Bartlett, Kon, Terry, Thompson, Walker, Briggs, Cotchin \& Lovell, 1949) the addition of I 50,000 i.u. vitamin A during the first 2 days of life to the diet of calves deprived of colostrum did not protect them from death. Later, it was found that, under our conditions, the survival of the newborn calf depended on a factor contained in the globulin fraction of colostrum and that as little as $\mathrm{I} 4 \mathrm{~g}$ of this fraction would protect most calves against death, even though they scoured badly and did not grow normally (Aschaffenburg, Bartlett, Kon, Roy, Walker, Briggs \& Lovell, 195 I). As calves had been found to grow well on relatively large quantities $(71$.) of either separated colostrum or milk containing $3.5 \%$ of crude colostral fat, i.e. a fat containing a small quantity of the non-fatty fraction, it was suggested (Aschaffenburg, Bartlett, Kon, Walker, Briggs, Cotchin \& Lovell, 1949) 
that lecithin, a component common to both these fractions of colostrum, might improve the growth of calves receiving only a small quantity of separated colostrum. It seemed also possible that a large quantity of vitamin A might improve the growth of calves once they had been protected from death by a small quantity of separated colostrum.

One experiment was therefore planned to discover whether calves given a small quantity of separated colostrum, supplemented with a large amount of vitamin A with or without soya-bean lecithin, would grow better than calves given a small quantity of separated colostrum alone. Moreover, we wished to obtain further information on the effect of soya-bean lecithin on the absorption of vitamin A by the calf. The results of this experiment suggested that the feeding of 3500 i.u. vitamin A daily to calves, our normal practice in all previous experiments, might mask the differences in vitamin A levels of blood plasma and livers of the calves between the treatments. Several treatments were therefore included in a second experiment in which this daily allowance was not given. In Exp. 2, a comparison was also made of the effect of lecithin and vitamin A on the survival of calves deprived of colostrum.

\section{Experiment I}

\section{METHODS}

\section{Plan of experiment}

This was done in the autumn of I950 after the calfhouse had been empty for $2 \frac{1}{2}$ months. A randomized block design was used, with five treatments in each of eight blocks of Shorthorn bull calves, as follows:

Treatment no.
0
I 8
I9
20
$2 \mathrm{r}$

\section{Initial diet}

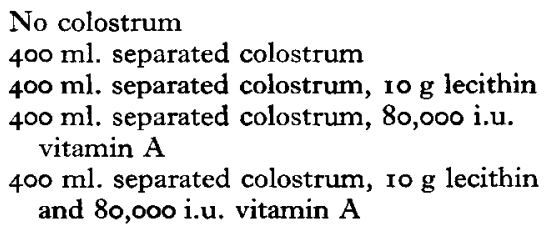

Besides the basic diet (see below) all calves received 3500 i.u. vitamin A and 700 i.u. vitamin $\mathrm{D}$ daily.

\section{Experiment 2}

This was done in the spring of $195 \mathrm{I}$ when, in contrast with the first experiment, the pens had been in use for 6 months, during which time ${ }_{1} 36$ calves had been on experiment. Six blocks of Shorthorn bull calves were used, except for treatment $\infty$, on which there were only four calves, as follows:

Treatment no
0
00
22
23
24
25
26

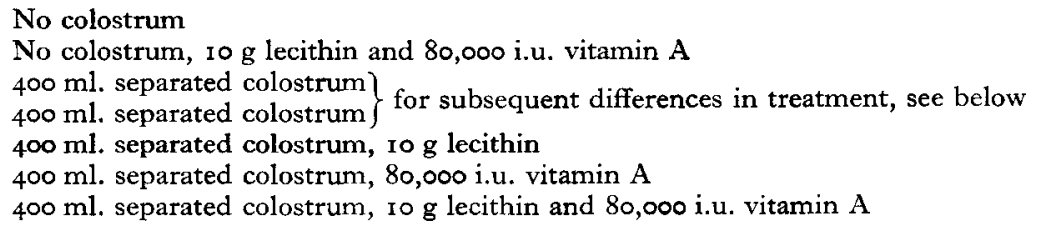


Besides the basic diet all calves received 700 i.u. vitamin D daily, but only calves on treatments $\circ$ and 22 were given 3500 i.u. vitamin A daily. Thus, treatments $O$ and 22 were identical with treatments 0 and 18 , respectively, in Exp. $x$.

\section{Basic diet}

\section{Diets}

The calves were reared on the 'synthetic milk' (Aschaffenburg, Bartlett, Kon, Terry et al. 1949) for 3 weeks; the daily allowance was I lb./1o lb. live weight, except when scouring occurred.

\section{Separated colostrum}

Batches of colostrum, obtained within $24 \mathrm{~h}$ of calving from Shorthorn cows, were warmed and passed twice through an ordinary cream separator. The separated colostrum was then stored at $-25^{\circ}$ until required. Four batches were blended in equal volumes, and each calf on treatments $18-26$ received $400 \mathrm{ml}$. in its first meal within $\mathrm{I} 2 \mathrm{~h}$ of birth. Each calf obtained from this source the following amounts of non-casein nitrogen (largely globulin).

$\begin{array}{llc} & \begin{array}{c}\text { Non-casein } \\ \text { nitrogen } \\ (\mathrm{g})\end{array} \\ \text { Exp. 1 : blocks I-7 } & 8 \cdot 6 \\ \text { Exp. 2: blocks I-6 } & 7 \cdot 4 \\ & \text { block } 8 \cdot 8\end{array}$

\section{Lecithin}

An aqueous emulsion, containing ro g of soya-bean lecithin in $100 \mathrm{ml}$., was homogenized into $300 \mathrm{ml}$. of 'synthetic milk'; $200 \mathrm{ml}$. of this diet were given with the first two feeds to each calf on treatments 19 and 24.

\section{Vitamin $A$}

Each calf on treatments 20 and 25 received 80,000 i.u. vitamin $A$ in the form of mixed fish-liver oil $(c .60,000$ i.u./g); the oil was homogenized into a small quantity of 'synthetic milk' so that the resulting volume was $400 \mathrm{ml}$.; $200 \mathrm{ml}$. of this were given to each calf with its first two feeds.

\section{Vitamin $A$ and lecithin}

Each calf on treatments $00,2 \mathrm{I}$ and 26 received $400 \mathrm{ml}$. of 'synthetic milk' containing 80,000 i.u. vitamin A and $10 \mathrm{~g}$ lecithin; $200 \mathrm{ml}$. were given to each calf with its first two feeds.

\section{Calves}

Collection and management of the calves, and treatment of the scouring calves, were as in earlier experiments (Aschaffenburg et al. 1951). In Exp. 2 a record was also kept of the time by which each of the calves had passed its meconium. Under our conditions this normally occurs within about $24 \mathrm{~h}$ of the first feed. Observations could thus be made on the possible relationship between the rate of passage of the meconium and the absorption of vitamin $A$ being administered at this time. 
All calves were bled from the jugular vein before their first feed, and on the $4^{\text {th }}$ and 2 Ist days of life. The vitamin A in the blood plasma was extracted by the method of Kimble (1939) and was then chromatographically separated (Ganguly, Kon \& Thompson, 1947).

The surviving calves were slaughtered at 3 weeks of age. Vitamin A was extracted from the livers by a method similar to that described by Davies (1933) and determined by the antimony-trichloride reaction in the photoelectric spectrophotometer of Thompson (1949).

\section{Statistical analysis}

The mortality rates of the calves on the various treatments were compared by the $\chi^{2}$ test adjusted for continuity. Multiple co-variance analysis was used for comparing the live-weight gains of the calves. As many calves died during Exp. 2, the randomized block arrangement was ignored in the analysis. The plasma levels and liver reserves of vitamin A were compared by analyses of variance and co-variance with the values for liver reserves $(x)$ transformed to $\log x$. The values for blood plasma and liver reserve of vitamin $A$ at 2 I days for one calf on treatment 22 were omitted, because it had a Corynebacterium pyogenes infection of the jaw during the last week of the experimental period. An abnormally low value for plasma vitamin A at 21 days $(3.0$ i.u. $/ 100 \mathrm{ml}$.) and an abnormally high total liver reserve (37,000 i.u.) were found for this calf, and replacement values were therefore calculated by the missing plot technique of Yates (1933).

\section{Mortality}

RESULTS

The results given in Table $\mathbf{I}$ show that in both experiments all calves deprived of colostrum died, and that the feeding of lecithin and vitamin A to such calves (treatment oo) did not reduce mortality. All the calves in Exp. I receiving $400 \mathrm{ml}$. of separated colostrum survived, whereas eight of thirty similarly treated calves died in Exp. 2; the deaths were fairly evenly distributed between the treatments. For calves that were deprived of colostrum, the mean age at death was significantly greater $(P<0.01)$ in Exp. I than in Exp. 2. In Exp. 2, those calves that died in spite of having received $400 \mathrm{ml}$. of separated colostrum lived significantly longer $(P<0.0 \mathrm{I})$ than those that were deprived of it.

\section{Incidence of scouring and of high rectal temperature $\left(>102 \cdot 8^{\circ} \mathrm{F}\right)$}

The results given in Table 2 show that there was no significant difference in scouring (assessed as described in Aschaffenburg, Bartlett, Kon, Terry et al. 1949) between calves on the different treatments within either experiment. In the second, scouring was twice as frequent as in the first. In both, nearly all calves scoured after the complete passage of meconium.

The number of days on which calves had a rectal temperature above $102.8^{\circ} \mathrm{F}$ did not differ significantly between treatments or experiments. Rectal temperatures above $102.8^{\circ} \mathrm{F}$ were regarded as high, because a mean value of $102 . \mathrm{I}^{\circ} \mathrm{F}$ (S.D. \pm 0.7$)$ had been obtained from an examination of over 3000 values for calves kept under our experimental conditions for 3 weeks. 


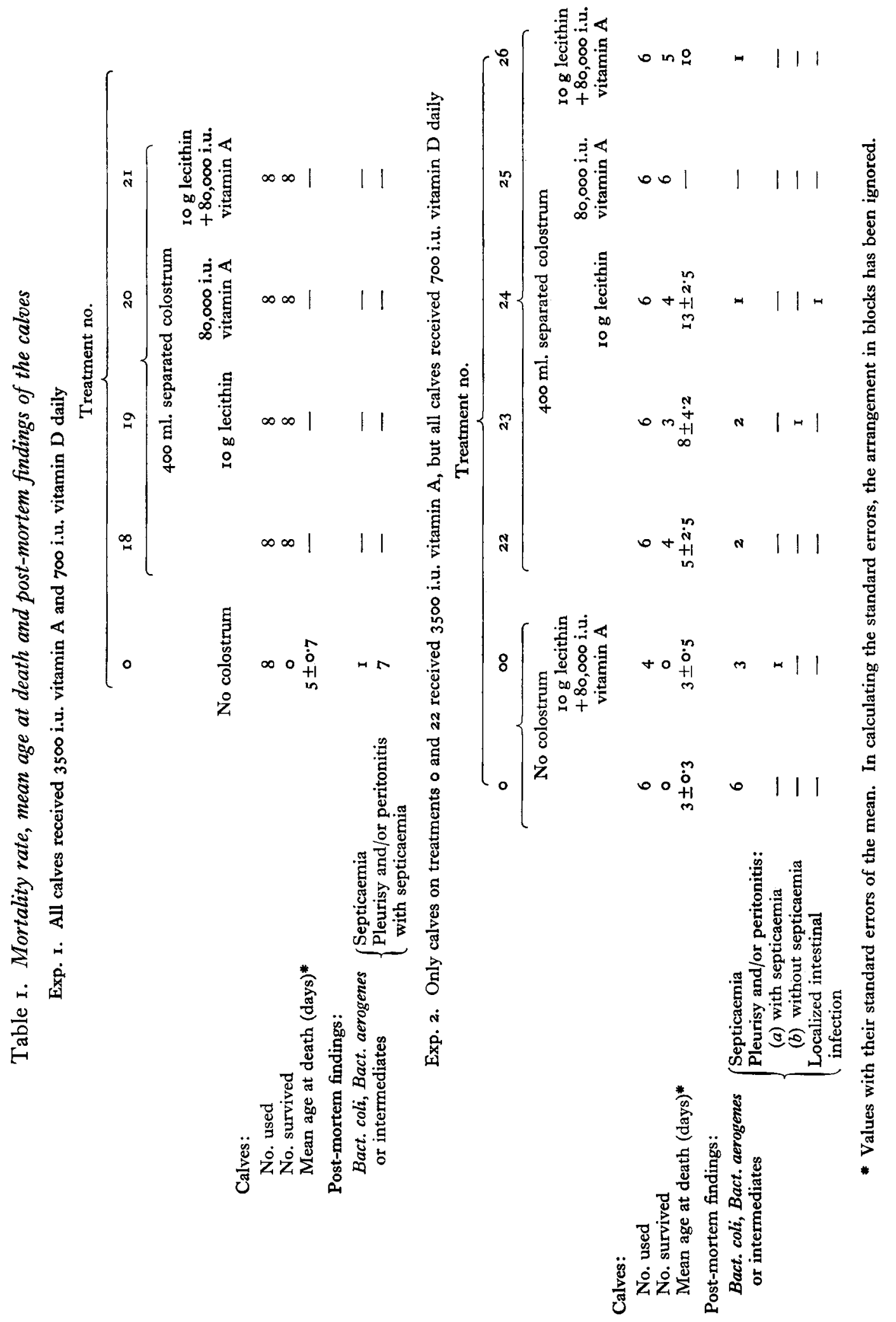




\section{Live-weight gain}

The mean daily live-weight gain for each treatment was obtained by fitting a linear regression to the twenty-one daily weights of surviving calves. There was no significant difference between treatments. However, when these mean daily live-weight gains were analysed by multiple co-variance and adjusted for the affecting variables, there

Table 2. Mean values with their standard errors for adjusted live-weight gain/day, the incidence of scouring and the incidence of a high rectal temperature $\left(>102.8^{\circ} \mathrm{F}\right)$ of the calves

Exp. I. All calves received 3500 i.u. vitamin A and 700 i.u. vitamin D daily

\begin{tabular}{|c|c|c|c|c|}
\hline \multirow[b]{4}{*}{ Adiusted mean live-weinht gainldaw (1h)* } & \multicolumn{4}{|c|}{ Treatment no. } \\
\hline & I 8 & $\begin{array}{l}\text { I9 } \\
400 \mathrm{ml} \text {. separ }\end{array}$ & $\begin{array}{l}20 \\
\text { ed colostrum }\end{array}$ & 21 \\
\hline & & $10 \mathrm{~g}$ lecithin & $\begin{array}{l}80,000 \text { i.u. } \\
\text { vitamin A }\end{array}$ & $\begin{array}{l}\text { Io g lecithin }+ \\
80,000 \text { i.u. } \\
\text { vitamin A }\end{array}$ \\
\hline & $0.50 \pm 0.04$ & $0.53 \pm 0.04$ & $0.44 \pm 0.05$ & $0.42 \pm 0.05$ \\
\hline $\begin{array}{l}\text { Mean no. of days on which calves } \\
\text { scoured*t }\end{array}$ & $4 \pm I \cdot 3$ & $4 \pm 0.9$ & $3 \pm 1 \cdot 0$ & $3 \pm 0.6$ \\
\hline $\begin{array}{l}\text { Mean no. of days on which calves had } \\
\text { a high rectal temperature }\left(>102.8^{\circ} \mathrm{F}\right)^{*}+\end{array}$ & $I \pm 0.4$ & $2 \pm 0.5$ & $3 \pm I \cdot 0$ & $I \pm 0.2$ \\
\hline
\end{tabular}

Exp. 2. Only calves on treatment 22 received 3500 i.u. vitamin $A$, but all calves received 700 i.u. vitamin $\mathrm{D}$ daily

Treatment no.

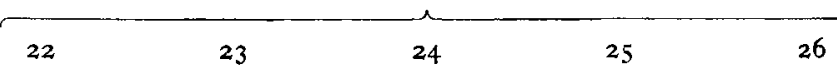

$400 \mathrm{ml}$. separated colostrum

Adjusted mean liveweight gain/day (lb.)*

Mean no. of days on which calves scoured* $\uparrow$

Mean no. of days on which calves had a high rectal temperature $\left(>102 \cdot 8^{\circ} \mathrm{F}\right)^{*}+$

* Means with their standard errors.

† In calculating the standard errors the arrangement in blocks has been ignored.

was an indication in both experiments that calves receiving an initial large quantity of vitamin $A$, with or without lecithin, grew less well than those given a daily allowance of vitamin A in Exp. I or deprived of vitamin A in Exp. 2. In neither were the differences quite significant at the $5 \%$ level. Results from the two experiments were not combined because of the difficulty of getting a valid estimate of the standard errors of the means. The affecting variables that had a significant effect on live-weight gain were birth weight, total milk consumption and the incidence of a rectal temperature above $102 \cdot 8^{\circ} \mathrm{F}$. The relevant partial regression coefficients with their standard errors for the two experiments are given in Table 3. Scouring did not significantly affect the live-weight gains, because the milk intake of the calves was considerably reduced 
when scouring occurred. The incidence of a high rectal temperature only affected live-weight gain in Exp. $\mathrm{r}$, where the scouring was not very severe. The weight gains in Exp. 2 were lower than those in Exp. $\mathrm{x}$, even for the identical treatments 18 and 22.

\section{Plasma levels of vitamin $A$}

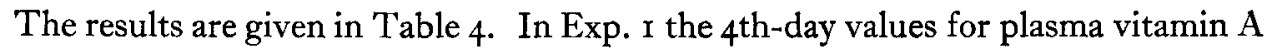
of calves receiving the large initial doses of vitamin $A$, with or without lecithin, were much higher than those of calves not so treated. By the 2 ist day the differences were still evident, but were smaller, no doubt because all calves had received 3500 i.u. vitamin A daily. Contrary to the findings of Esh et al. (1948), who, however, gave lecithin and vitamin A for 7 days, the addition of lecithin to the vitamin A did not, in our experiments, give blood-plasma levels significantly above those obtained with vitamin $\mathrm{A}$ alone.

Table 3. Partial regression coefficient of live-weight gain/day (lb.) on birth weight (lb.) total milk consumption (pints) and incidence of a high rectal temperature $\left(>102 \cdot 8^{\circ} \mathrm{F}\right)$

\begin{tabular}{|c|c|c|c|c|}
\hline & \multicolumn{2}{|r|}{ Exp. I } & \multicolumn{2}{|r|}{ Exp. 2} \\
\hline & $\begin{array}{l}\text { General } \\
\text { mean }\end{array}$ & $\begin{array}{l}\text { Partial regression } \\
\text { coefficient with its } \\
\text { standard error }\end{array}$ & $\begin{array}{c}\text { General } \\
\text { mean }\end{array}$ & $\begin{array}{l}\text { Partial regression } \\
\text { coefficient with its } \\
\text { standard error }\end{array}$ \\
\hline Live-weight gain/day (lb.) & 0.475 & - & $0 \cdot 300$ & - \\
\hline Birth weight (lb.) & $76 \cdot 73$ & $-0.0143 \pm 0.0037^{* *}$ & $85 \cdot 50$ & $-0.0141 \pm 0.0046^{* *}$ \\
\hline $\begin{array}{l}\text { Total milk consumption } \\
\text { (pints) }\end{array}$ & 110.49 & $0.0171 \pm 0.0014^{* * *}$ & 102.79 & $0.0164 \pm 0.0025^{* * *}$ \\
\hline $\begin{array}{l}\text { No. of days on which calves } \\
\text { had a high rectal tempera- } \\
\text { ture }\left(>\text { IO2. } 8^{\circ} \mathrm{F}\right) \text {. (Values } \\
\left.\text { transformed } \sqrt{ }\left(x+\frac{1}{2}\right)\right)\end{array}$ & $I \cdot 306$ & $-0.1853 \pm 0.0467 * * *$ & 一 & 一 \\
\hline
\end{tabular}

$$
\text { ** Significant at } P<0.01 \text {. }
$$$$
\text { **** Significant at } P<0.001 \text {. }
$$

The 4th-day results for treatments $23-26$ in Exp. 2 were similar. Further, the plasma vitamin $A$ of calves given a large initial dose of vitamin $A$ together with lecithin, but not the daily supplement of 3500 i.u. (treatment 26 ), was significantly greater than that of calves given only the daily supplement of vitamin A (treatment 22). A large initial dose of vitamin A alone (treatment 25) did not have a significant effect. By the 2Ist day the plasma vitamin A of calves that had received a large initial dose of vitamin A with or without lecithin appeared greater than that of calves deprived of it from birth (treatments 23 and 24), but only when lecithin had been given as well as vitamin $\mathrm{A}$ was this difference significant. The plasma vitamin $\mathrm{A}$ of calves on treatment 22, which had received 3500 i.u. vitamin A daily, was significantly higher at 2I days than that of calves that had been deprived of vitamin A from birth (treatments 23 and 24) or had had a large initial dose of vitamin A (treatment 25). The plasma level of calves on treatment 22 was, however, of the same order as that of calves given lecithin with the initial dose of vitamin A (treatment 26).

Co-variance analysis of the increase in plasma vitamin A levels during the first 4 days of life showed that the increase, irrespective of treatment, was related to the plasma levels at birth. The increases adjusted for initial plasma level are given in 
$\frac{3}{8}$

సँ

.

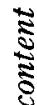

కี

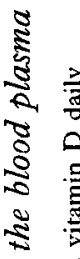

.

ए :

.

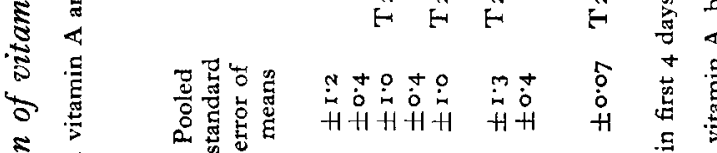

空

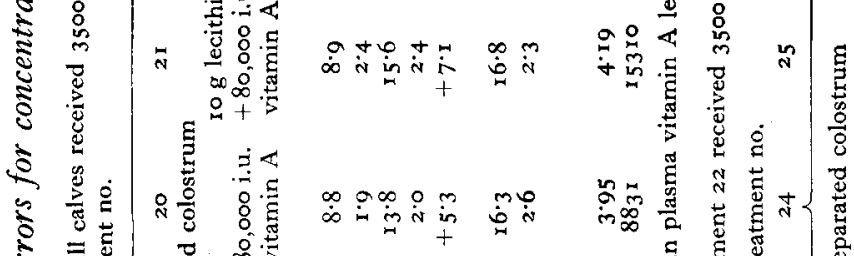

$\sqrt[3]{2}$

密

ริ

$\stackrel{\dot{4}}{\frac{0}{\pi}}$

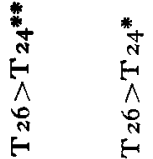

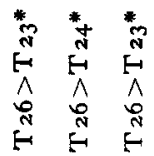

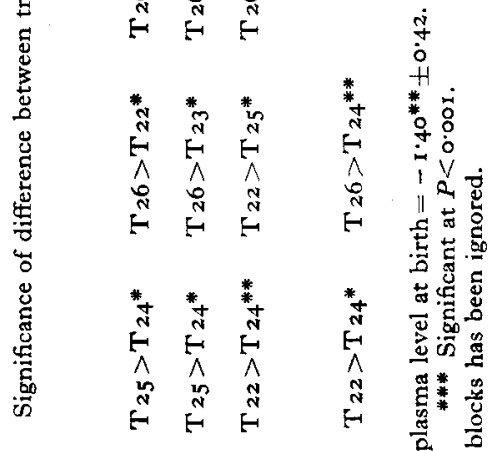

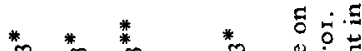

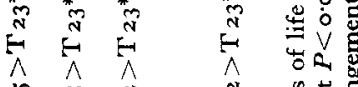

की

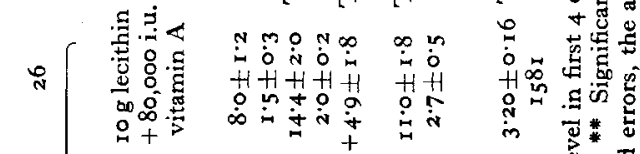

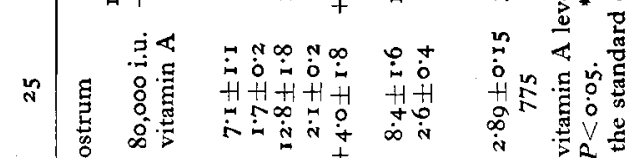

ह

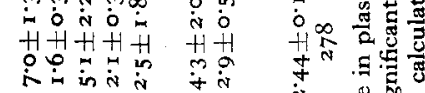

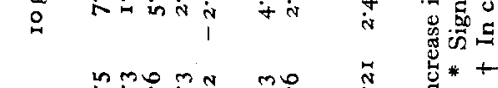

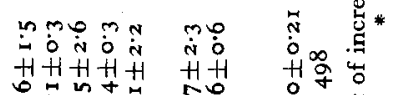

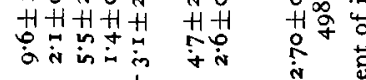

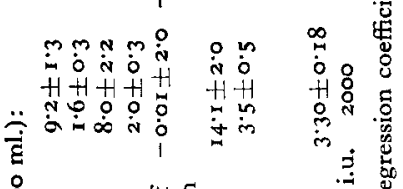

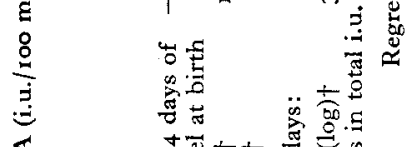

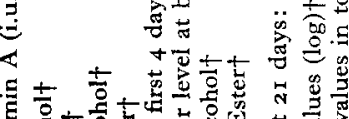

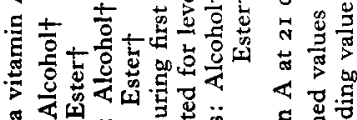

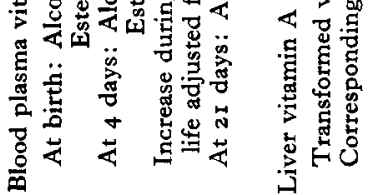


Table 4, together with the regression coefficients. Thus, when there was an increase, high plasma levels of vitamin A at birth increased less than low levels. When on the other hand, there was a decrease, high plasma levels fell more than low ones.

\section{Liver reserves of vitamin $A$}

In Exp. I, the calves that had received a large initial dose of vitamin A with or without lecithin had much higher liver reserves than those receiving other treatments. Lecithin with vitamin A gave significantly higher liver reserves than did vitamin A alone.

In Exp. 2, the results were not so clear-cut, probably because there was more scouring. With the treatments in which the daily supplement of 3500 i.u vitamin A had been withheld, the liver reserves were much lower than in Exp. 1. The liver reserves of calves that had received a large initial dose of vitamin A (treatment 25) did not differ significantly from those of calves deprived of vitamin $A$ from birth (treatments 23 and 24). When lecithin was given with 80,000 i.u. vitamin A (treatment 26) the liver reserves were significantly higher than those of calves given lecithin alone (treatment 24), but not significantly higher than those of calves on treatment 23 . The calves on treatment 22 , having a daily supplement of 3500 i.u. vitamin A, had total liver reserves similar to those on the corresponding treatment 18 in Exp. I. It thus seems likely that at birth the liver reserves of the calves born in the autumn (Exp. I) did not differ very much from those of calves born in the spring (Exp. 2). The liver reserves of calves on treatment 22 were significantly higher than those of calves that had received no vitamin A at all since birth (treatments 23 and 24). The addition of lecithin to an initial large dose of vitamin $A$ appeared to increase the liver reserves, but, in contrast to Exp. I, the increase was not significant.

Regression analysis showed that the great variation in the liver reserves of the calves that received in Exp. 2 a large initial dose of vitamin A with or without lecithin could partly be accounted for by differences in the rate of the passage of meconium. The regression equation of $\log$ liver reserves at $2 \mathrm{I}$ days $(y)$ on the period, measured in hours, between the first feed and the complete passage of the meconium $(x)$ was as follows:

$$
y=3.03+0.068(x-2 \text { r.03 }), \text { S.E. }=0.020 .
$$

The regression coefficient was significant $(P<0 \cdot 01)$.

\section{Post-mortem and serological findings}

Table I shows the post-mortem findings for calves in both experiments. Of the twenty-six calves that died, twenty-four had a Bacterium coli septicaemia, and of these eight had a pleurisy or peritonitis. No organisms could be recovered from the tissues of the two remaining calves at post-mortem, although lesions indicated colibacillosis. The blended colostrum contained agglutinins against all except two of the strains of Bact. coli, isolated from contemporary calves that died. 
As in earlier experiments, $400 \mathrm{ml}$. of separated colostrum usually protected calves from death. The greater number of deaths in Exp. 2 can possibly be accounted for in the following way. First, the chance of infection was probably greater after the calfhouse had been occupied for a long time; secondly, the $400 \mathrm{ml}$. of separated colostrum contained less protein, as shown by the non-casein nitrogen values, than was given in Exp. I; lastly, there were present in the calfhouse during Exp. 2 strains of Bact. coli against which the colostrum gave no protection. These factors, no doubt, contributed also to the greater incidence of scouring and to the shorter life of colostrum-deprived calves.

The feeding of lecithin together with vitamin A did not affect the mortality rate of calves deprived of colostrum. This result differs from that of Esh et al. (1948), but they gave lecithin and vitamin $\mathrm{A}$ for the first 7 days of life.

In both experiments there was an indication that calves given large initial doses of vitamin A with or without lecithin did not grow as well as those not so treated. The reason for this depression in growth rate, if it is in fact real, is not known, and we propose to investigate the problem. The calves in Exp. 2 not receiving any vitamin A (treatments 23 and 24) showed no obvious signs of vitamin A deficiency, and they grew as well as, if not better than, those given a large initial dose of vitamin A.

The results of Exp. I have confirmed the findings of Esh et al. (1948) that feeding soya-bean lecithin with vitamin A increases the liver reserves of the young calf more than feeding vitamin $\mathrm{A}$ alone. The failure to confirm these findings in Exp. 2 was probably due to the greater incidence of scouring during this period. Our findings about the relationship between the rate of passage of the meconium and the liver reserves add further weight to the observation of Sellers \& Eden (1949) that after similar amounts of vitamin A had been given, scouring calves had lower liver reserves than normal healthy calves. They suggested that the increased rate of passage of food decreased the absorption of vitamin A. Our results give little support to the suggestion of Esh et al. (1948) that the feeding of lecithin with vitamin A results in higher plasma levels than the feeding of vitamin A alone. These authors had only three calves that survived for 7 days after receiving vitamin $A$ alone, and these had received considerably less vitamin $\mathrm{A}$ than the calves that had lecithin as well.

The negative relationship between the initial plasma level of vitamin A and the magnitude of change resulting from depletion or addition indicates the existence of an upper and a lower threshold level of plasma vitamin A.

These experiments afford no evidence for believing that the subnormal growth rate of calves given small quantities of separated colostrum can be improved by adding lecithin and a large amount of vitamin A to their initial diet. When the growth rate of calves is limited by severe scouring, as in our second experiment, there is no indication that depriving the calves of vitamin A leads to deficiency symptoms during the first 3 weeks of life, although it can be seen from Table 4 that the liver reserves of such calves were nearly exhausted by the end of the experimental period. 


\section{SUMMARY}

I. Eighty Shorthorn bull calves were used in two experiments, one in the autumn and one in the spring, to test the effect of soya-bean lecithin on the growth rate and on the absorption of vitamin $\mathrm{A}$, measured by plasma levels and by the liver reserves on the 2 ist day.

2. Eighteen calves were deprived of colostrum, and sixty-two received $400 \mathrm{ml}$. of separated colostrum. The calves were kept for 3 weeks on a standard diet based on dried skim milk.

3. All the calves deprived of colostrum died even when they had received lecithin and vitamin A. Of the calves given $400 \mathrm{ml}$. of separated colostrum, in Exp. I none died, but in Exp. 2 eight out of thirty died.

4. The feeding of vitamin A with or without lecithin had no significant effect on scouring, on the incidence of a high rectal temperature or on the growth rate of the calves.

5. In the first experiment, but not in the second, the feeding of lecithin and vitamin $A$ increased the liver reserves of vitamin A significantly above those resulting from feeding vitamin $A$ alone. In both, the addition of lecithin to vitamin $A$ did not increase the plasma levels above those obtained with vitamin $\mathrm{A}$ alone.

The work carried out by Mr P. C. Wood was done under a special grant from the Agricultural Research Council.

We wish to thank Mrs Henschel for carrying out the analytical work connected with the estimation of vitamin A; Miss J. Palmer for her help with statistical analysis of the results; Messrs Marcom Limited for supplying the special non-vitaminized margarine and Mr W. B. Barbour of the Scottish Milk Powder Company Ltd. for his help with supplies of dried milk.

\section{REFERENCES}

Aschaffenburg, R., Bartlett, S., Kon, S. K., Terry, P., Thompson, S. Y., Walker, D. M., Briggs, C., Cotchin, E. \& Lovell, R. (1949). Brit. F. Nutr. 3, 187.

Aschaffenburg, R., Bartlett, S., Kon, S. K., Roy, J. H. B., Walker, D. M., Briggs, C. \& Lovell, R. (1951). Brit. F. Nutr. 5, I7I.

Aschaffenburg, R., Bartlett, S., Kon, S. K., Walker, D. M., Briggs, C., Cotchin, E., \& Lovell, R. (1949). Brit. F. Nutr. 3, I 96.

Davies, A. W. (1933). Biochem. F. $27,1770$.

Esh, G. C. \& Sutton, T. S. (1948). F. Nutr. 36, 39 r.

Esh, G. C., Sutton, T. S., Hibbs, J. W. \& Krauss, W. E. (1948). F. Dairy Sci. 3r, 46 I.

Ganguly, J., Kon, S. K. \& Thompson, S. Y. (I947). Brit. F. Nutr. I, iii.

Kimble, M. S. (1939). F. Lab. clin. Med. 24, 1055.

Sellers, K. C. \& Eden, E. (1949). F. comp. Path. 59, 205.

Sheffy, B. E., Gallegos, A. C., Grummer, R. H., Phillips, P. H. \& Bohstedt, G. (195 I). F. Anim. Sci. ro, 867 .

Thompson, S. Y. (1949). Brit. F. Nutr. 3, 43.

Yates, F. (1933). Emp. F. exp. Agric. I, 129. 